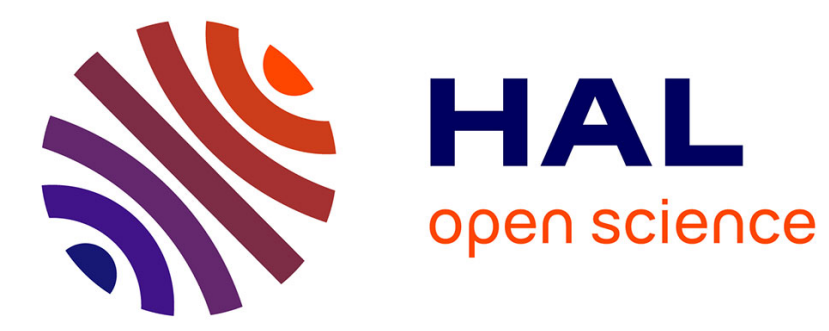

\title{
Electromagnetic Absorbers and Normalization
}

\author{
F. Mayer
}

\section{To cite this version:}

F. Mayer. Electromagnetic Absorbers and Normalization. Journal de Physique IV Proceedings, 1997, 07 (C1), pp.C1-431-C1-432. 10.1051/jp4:19971175 . jpa-00254823

\section{HAL Id: jpa-00254823 https://hal.science/jpa-00254823}

Submitted on 1 Jan 1997

HAL is a multi-disciplinary open access archive for the deposit and dissemination of scientific research documents, whether they are published or not. The documents may come from teaching and research institutions in France or abroad, or from public or private research centers.
L'archive ouverte pluridisciplinaire HAL, est destinée au dépôt et à la diffusion de documents scientifiques de niveau recherche, publiés ou non, émanant des établissements d'enseignement et de recherche français ou étrangers, des laboratoires publics ou privés. 


\title{
Electromagnetic Absorbers and Normalization
}

F. Mayer

LEAD, 12 avenue de la République, 94700 Maisons-Alfort

\begin{abstract}
The IEEE Recommended Practice of RF-Absorber Evaluation in the Range $30 \mathrm{MHz}$ to 5 GHz (PAR1128) is a good exauple of the "global" procedures, where worldwide EMC engineers can actively participate, and indeed make the PAR, and the future Standard a global event. We sumarize hereunder the contents of the current document (about 70 pages) which has needed three years to establish, because of the permanent interactions :
\end{abstract}

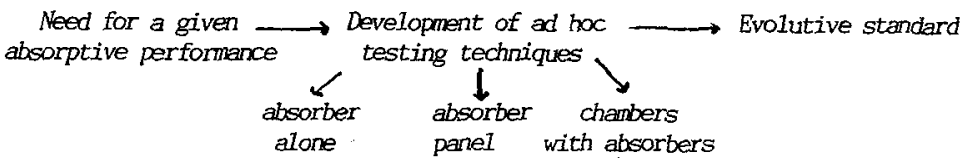

\section{INIRODUCTION}

This IEEE Recommended Practice is a first attempt to give Mamufacturers of $R F$ Absorbers guide lines on how and what to measure in order to describe the performance of such materials.

This performance should be such that it can be utilized by the Users in the various equipments necessary to perform the measurements.

Next, procechures to characterize the bulk paraneters of $R F$ Absorbers are discussed.

This is followed by a discussion of the various methods used to measure the performance of RF Absorbers.

Next methods to evaluate the performance of applications of RF Absorbers are discussed.

Finally, recommended reporting procedures of the results of such measurements are outlined.

PARI128 is not intended to be a definitive and detailed description on how to perform the various measurements discussed but only a sketch of how it can be done using presently available techniques.

Details of the procechures have to be developed by the manufacturers, for their particular line of prom ducts, and are a function of the availability of new technology and equipment.

\section{FOREWOAD}

Interest in materials that absorb radio frequency energy has existed for many years. The recent increased regulation of sources of radio waves and equipment imannity has led to the need for more accurate determination of the electronagnetic field intensity.

As modem measuring antennas and receivers have increased measurements acauracy, the problem of making accurate measurements in less than optimum open-field environments has become a more important part of the overal measuring scene.

The practice of placing absorbing materials on the walls and ceiling of measuring sites to reduce reflections from these surfaces has become common.

However, claims for the efficacy of various absorbing materials have led to conflicting reports in the literature, confusing many potential purchasers of absorbing material.

An effort to end that confusion led to the development of PAR1128 in 1996. Following several years of work, the current doament was developed. 
Emphasis is put on the evolutionary aspects of the document, "guaranteed to change". New absorbers, with broader bandwidths and better reflectivity performances, are described, based upon progress in the science of new ferrites, with special designed permeability and permittivity spectra.

\section{CONIENIS : HEADLINES}

1. Introduction

2. References

3. Definitions

4. Measurement instrumentation

4.1. Spectrum analysers

4.2. Spectrum analyser and tracking generator

4.3. EMI receiver

4.4. Vector network analysers

4.5. Scaler network analysers

4.6. Vector voltmeters

4.7. Time domain reflectometers

4.8. EMC antennas

5. Test enviroment parameter guidelines

6. Meterial bulk parameter evaluation (I)

6.1. Background

6.2. Bulk parameters measurement procedures
7. Evaluation of the reflectivity of $R F$ absorbers

7.1. Backgraind

7.2. $R F$ absorbers reflectivity measurement procedures 7.2.1. The arch method measurement procedure 7.2.2. The time domain measurement procecture 7.2.3. The enclosed measurement procecture

8. $R F$ absorbers perfonmance in absorber lined open 8.1. Background area test sites and chambers

8.2. ATS and ALC measurement procecture

8.3. Semi-anechoic chambers measurement procedure

9. Test reports

9.1. Test report content

9.2. Test report disposition

10. Bibliography

11. Appendices

\section{CONIENIS : COMENIS}

Copyright to IEEE. All rights reserved. This is an unapproved IELE Recomended Practice Draft, guaranted to change. March 17, 1995

Chapter 1 to 5 describe the reason of the now forthcoming replacement of pyramidal resistive absorbers by ferrite absorbers, especially due to the low frequency reflectivity needs.

Chapter 6 to 8 describe the problems of evaluation of the reflectivity : from basic material testing (small samples) and simulation from $\mu$ and 6 spectra, to surface testing (several square meter surfaces), to finally overall performance in an anechoic chamber.

Several specific items will be described in detail :

Definition of Site Attenuation, with rew criteria, conceming non-vertical wave incidence. Importance of compasite ferrite-resistive pyramidal absorbers; forthcoming multilayer ferrite-absorbers. Current ferrites with controlled magnetic dispersion and low dielectric dispersion. New ferrites with controlled magnetic dispersion and dielectric dispersion. Research on co-fired compasite ferrite absorbers. Perspectives for the passibility to cover the $30 \mathrm{MHz}-18 \mathrm{GHz}$ frequency range. 